\title{
Prenatal Excess Glucocorticoid Exposure and Adult Affective Disorders: A Role for Serotonergic and Catecholamine Pathways
}

\author{
Caitlin S. Wyrwoll Megan C. Holmes \\ Endocrinology Unit, Centre for Cardiovascular Science, Queen's Medical Research Institute, The University of \\ Edinburgh, Edinburgh, UK
}

\section{Key Words}

Glucocorticoid - 11 $\beta$-HSD2 - Developmental programming • Anxiety $\cdot$ Depression $\cdot$ Serotonin $\cdot$ Dopamine

\begin{abstract}
Fetal glucocorticoid exposure is a key mechanism proposed to underlie prenatal 'programming' of adult affective behaviours such as depression and anxiety. Indeed, the glucocorticoid metabolising enzyme $11 \beta$-hydroxysteroid dehydrogenase type 2 (11ß-HSD2), which is highly expressed in the placenta and the developing fetus, acts as a protective barrier from the high maternal glucocorticoids which may alter developmental trajectories. The programmed changes resulting from maternal stress or bypass or from the inhibition of $11 \beta-H S D 2$ are frequently associated with alterations in the hypothalamic-pituitary-adrenal (HPA) axis. Hence, circulating glucocorticoid levels are increased either basally or in response to stress accompanied by CNS region-specific modulations in the expression of both corticosteroid receptors (mineralocorticoid and glucocorticoid receptors). Furthermore, early-life glucocorticoid exposure also affects serotonergic and catecholamine pathways within the brain, with changes in both associated neurotransmitters and receptors. Indeed, global removal of $11 \beta-H S D 2$, an enzyme
\end{abstract}

that inactivates glucocorticoids, increases anxiety- and depressive-like behaviour in mice; however, in this case the phenotype is not accompanied by overt perturbation in the HPA axis but, intriguingly, alterations in serotonergic and catecholamine pathways are maintained in this programming model. This review addresses one of the potential adverse effects of glucocorticoid overexposure in utero, i.e. increased incidence of affective behaviours, and the mechanisms underlying these behaviours including alteration of the HPA axis and serotonergic and catecholamine pathways.

Copyright $\odot 2011$ S. Karger AG, Basel

\section{Developmental Programming}

Low birth weight and other indicators of reduced fetal growth are associated with adult cardio-metabolic and psychiatric diseases. This association is the result of 'developmental programming', whereby a stimulus during a sensitive period of early development exerts permanent effects on structure, physiology or metabolism [1]. The environmental mechanisms of developmental programming identified so far can be simplified into two major groups: fetal stress exposure and maternal nutrition, although changes in glucocorticoids appear to underpin

\section{KARGER}

(C) 2011 S. Karger AG, Basel

Fax +41613061234

E-Mail karger@karger.ch

www.karger.com
Accessible online at:

www.karger.com/nen
C.S. Wyrwoll

Endocrinology Unit, Centre for Cardiovascular Science

Queen's Medical Research Institute, 47 Little France Crescent

Edinburgh EH16 4TJ (UK)

Tel. +44 131242 6746, E-Mail cwyrwoll@staffmail.ed.ac.uk 
the programming effects of both [2-4]. In many mammals, including mice and humans, there is an increased exposure of the developing fetus to glucocorticoids late in pregnancy, as they have a crucial role in the structural development and functional maturation of fetal organs. However, glucocorticoid overexposure of the fetus can be detrimental as glucocorticoids cause a shift from cell proliferation to differentiation. Therefore, exposure to excess glucocorticoids in utero alters fetal organ growth and maturation patterns, which can result in adverse consequences in later life. In humans, the actions of glucocorticoids are exploited for preterm births to advance fetal lung maturation [5], although this may set the stage for adverse effects in later life [6-16]. This review addresses one of the potential adverse effects of glucocorticoid overexposure in utero, i.e. increased incidence of affective behaviours, and the mechanisms underlying these behaviours including alteration of the hypothalamic-pituitaryadrenal (HPA) axis and serotonergic and catecholamine pathways.

\section{The Feto-Placental Glucocorticoid Barrier: 11ß-Hydroxysteroid Dehydrogenase Type 2}

As glucocorticoids are highly lipophilic, they readily diffuse across biological membranes and, therefore, control of intracellular levels of bioactive glucocorticoids is critical. This control arises from the enzyme 11ß-hydroxysteroid dehydrogenase (11 $\beta-H S D)$ which interconverts the active glucocorticoids cortisol and corticosterone with their biologically inactive forms, cortisone and 11-dehydrocorticosterone, respectively. There are two distinct forms of $11 \beta-H S D$ : $11 \beta-H S D 1$ is a low-affinity, $\operatorname{NADP}(\mathrm{H})$-dependent bidirectional enzyme, although in vivo it appears to act predominantly as an $11 \beta$-oxoreductase to enhance glucocorticoid activity. $11 \beta-H S D 2$ is a high-affinity NAD-dependent enzyme which exhibits exclusive $11 \beta$-dehydrogenase activity (conversion of corticosterone to 11-dehydrocorticosterone) to reduce glucocorticoid potency. 11 $\beta$-HSD2 is highly expressed in aldosterone-selective target tissues such as the distal nephron [17], colon [18], salivary glands [19] and skin [20], thus serving to confer aldosterone specificity on the mineralocorticoid receptor (MR) to which both corticosterone and aldosterone can bind. Importantly, 11ß-HSD2 does not always colocalise with MR, such as within placental and fetal tissues, and so its function has expanded beyond its involvement in the electrolyte transport to include regulation of corticosteroid action.
During much of normal pregnancy, circulating levels of glucocorticoids in the fetus are substantially lower than in the mother. This difference arises in part from the high expression of $11 \beta-H S D 2$ in both the placenta and fetus, and this $11 \beta-H S D 2$ expression serves as a 'glucocorticoid barrier', thus enabling a tight regulation of the materno-fetal glucocorticoid transfer. Within the placenta, $11 \beta-H S D 2$ is highly expressed at the interface between maternal and fetal circulations, in the syncytiotrophoblast in humans [16] and the labyrinthine zone in rodents [21]. In the rodent, $11 \beta-H S D 2$ expression within the labyrinth zone of the placenta falls during late gestation, which may facilitate glucocorticoid passage to the fetus and thus lung maturation $[22,23]$.

Within fetal tissues, $11 \beta-H S D 2$ is broadly expressed, particularly within the brain [23]. 11ß-HSD2 is abundant in the neuroepithelium throughout mid-gestation and then strikingly and rapidly declines, coinciding with the terminal stage of neurogenesis $[23,24]$. Similar patterns of expression occur in the human fetal brain, with $11 \beta$ HSD2 silenced between gestational weeks 19 and 26 [25]. Thus, this abundance and expression pattern of $11 \beta$ HSD2 suggests that $11 \beta$-HSD2 acts to protect immature mitotically active brain cells from premature exposure to the maturational effects of glucocorticoids. After birth, high levels of $11 \beta-H S D 2$ are localised in mice to only the proliferating external granular layer of the cerebellum and in several nuclei of the thalamus $[26,27]$. Therefore, in the early postnatal period the cerebellum is sensitive to glucocorticoid-induced remodelling caused either by exogenous administration or in response to the stress induced by maternal separation [28-30].

The high expression of $11 \beta-H S D 2$ in placenta and fetal tissues and the growth retarding and maturational effects of glucocorticoids on the fetus [31] have led to the proposal that variations in feto-placental $11 \beta-H S D 2$ may underlie developmental programming. Thus, placental $11 \beta-H S D 2$ activity correlates with birth parameters in rodents and, less consistently, in humans [7, 32, 33], suggesting that normal variation in fetal exposure to maternal glucocorticoids may impact on fetal growth. Numerous studies have shown that inhibition, deficiency or bypass (poor substrate steroids such as dexamethasone or betamethasone) of $11 \beta-H S D 2$ in gestation in rodents and humans associates with alterations in pregnancy duration, birth weight and programmed outcomes in the offspring [7, 15, 34-45]. Furthermore, maternal stress of rodents during pregnancy has been associated with a decreased expression of placental 11ß-HSD2 [46-48]. Interestingly, in programming models involving mater- 
nal low-protein diet, there is an increase in maternal and fetal glucocorticoid levels $[49,50]$ in addition to a decrease in placental 11 $\beta$-HSD2 activity and/or expression [50-52]. Moreover, dexamethasone administration during pregnancy decreases food intake [53]. Consequently, there seems to be considerable overlap in mechanisms by which maternal undernutrition and fetal glucocorticoid overexposure elicit developmental programming.

\section{Developmental Programming of Affective Disorders}

The developing brain, as other fetal tissues, is extremely sensitive to glucocorticoids, which are crucial for normal cellular and biochemical maturation [54, 55]. Thus, glucocorticoids initiate terminal maturation, remodel axons and dendrites and determine programmed cell death [31]. In sheep, prenatal glucocorticoid administration retards brain weight at birth [56], delaying maturation of neurons, myelination, glia and vasculature [57]. The perinatal hippocampus is especially sensitive to glucocorticoids, with consequences for subsequent memory and behaviour [58-60]. Thus, antenatal treatment of rhesus monkeys with dexamethasone causes a dose-associated degeneration of hippocampal neurones and reduced hippocampal volume which persists at 20 months of age [61]. Prenatal stress (induced by repeated restraint of the pregnant female in the last week of pregnancy) reduces actively proliferating hippocampal cells and feminises sexually dimorphic parameters of the adult hippocampus [62].

A critical outcome of excess glucocorticoid exposure in early life is the programming of affective function. In the rat, central programming by glucocorticoids, be it from maternal administration of dexamethasone or prenatal stress, produces offspring that appear more anxious as adults. Thus, late-gestational dexamethasone exposure in rats impairs the offspring's 'coping' behaviours in aversive situations later in life, as exemplified by reduced exploration in the open field test and elevated plus maze [42]. Such increase in anxiety-like behaviour is evident as early as postnatal week 10 in rats prenatally exposed to dexamethasone [63]. In rodents, prenatal stress increases depressive-like symptoms with an increased immobility time in the forced swim test and tail suspension test and anhedonia [64], although not always [65]. Furthermore, offspring of prenatally stressed rats are anxious, with less time spent in the anxiogenic open arms of the elevated plus maze [66-68] and altered behaviour in the open field test [69-71].

Prenatal Excess Glucocorticoid Exposure and Adult Affective Disorders
In animal models of antenatal glucocorticoid administration, prenatal stress and maternal dietary restriction, these programmed changes in behaviour are frequently accompanied by alterations in the HPA axis. Thus, maternal dexamethasone treatment increases corticosterone and adrenocorticotrophic hormone (ACTH) levels in the adult offspring, although, interestingly, mostly in males $[13,39,42,72]$. These effects seem to reflect a change in the feedback of the HPA axis at the level of the hypothalamus, as corticotrophin-releasing hormone $(\mathrm{CRH}) \mathrm{mRNA}$ increases in the paraventricular nucleus, whereas the hippocampal MR and glucocorticoid receptor (GR) both decrease [41, 73]. Furthermore, the HPA axis period of hyporesponsiveness in early postnatal life is abolished in adult rats exposed to prenatal stress [74], whilst normal age-related HPA axis dysfunction is accelerated by prenatal stress [75]. In sheep, a single injection of betamethasone on gestational day 104 alters the HPA axis function in offspring at 1 year of age, with elevated basal and stimulated plasma cortisol concentrations [76]. In contrast, repeated maternal betamethasone injections elevated the offspring's ACTH responses to a CRH/arginine vasopressin challenge in addition to increased basal ACTH levels but decreased basal and stimulated cortisol levels $[76,77]$. In primates, offspring of mothers treated with dexamethasone during late pregnancy have elevated basal and stress-stimulated cortisol levels [78, 79].

Moreover, prenatal stress and alterations in the offspring's HPA axis function have also been associated in humans. Thus, children of mothers present at or near to the World Trade Center atrocity on 9/11, who themselves developed symptoms of post-traumatic stress disorder (PTSD), had lower cortisol levels [80]. Importantly, these changes were most apparent in babies born to mothers who were in the last 3 months of their pregnancies when the trauma occurred, suggesting these observations can be attributed to developmental programming phenomena rather than to a genetic susceptibility or the presence of PTSD per se [80]. Such effects may transmit into subsequent generations, since healthy adult children of Holocaust survivors with PTSD (and therefore lower plasma cortisol levels) themselves have lower cortisol levels though no PTSD [81]. This appears to be confined to the children of Holocaust-exposed mothers with PTSD [81]. In contrast to PTSD, maternal anxiety and depression seem to elevate cortisol in the child $[82,83]$. Therefore, the mechanisms of prenatal stress programming HPA axis function in humans seem complex, with possibly different pathways involved. Intriguingly, in Finland, women who voluntarily ingest liquorice-containing 
foodstuffs (that potently inhibit placental 11 $\beta$-HSD2 [84]) in pregnancy have somewhat shorter gestations and their 8-year-old offspring show altered cognitive function, affective disturbances (notably markedly increased rates of attention-deficit/hyperactivity disorder), HPA axis hyperactivity and sleep disturbances $[85,86]$. However, while it is tempting to conclude that an altered HPA axis response is the underlying mechanism to anxietyrelated behaviour, it is important to note that these behavioural changes can occur in the absence of HPA axis alteration [70, 87].

\section{Gaining Functional Insight: Genetic Modifications of 11ß-HSD2}

As $11 \beta$-HSD2 appears to be a hub for eliciting programming effects, genetically modified mouse models have provided useful insight into underlying mechanisms. An initial mouse model of targeted $11 \beta$-HSD2 disruption on an outbred MF1 background revealed mice with an apparently normal phenotype at birth; however, within $48 \mathrm{~h}, 50 \%$ exhibit motor deficiencies, perhaps due to hypokalaemia, and die [88]. Survivors are fertile, but exhibit severe hypertension, hypokalaemia and polyuria [88], all typical characteristics of apparent mineralocorticoid excess and, thus, apparent mineralocorticoid actions of corticosterone were revealed by $11 \beta-\mathrm{HSD} 2$ deficiency. Interestingly, these mice did not exhibit reduced fetal weight, although this was clearly apparent in later studies on a $11 \beta-H S D 2$ knockout model congenic on a C57BL/6J background [35]. In assessing the relevance of $11 \beta-H S D 2$ in developmental programming, two separate breeding approaches have been taken. In homozygous breeding experiments, male and female mice null or wild-type for $11 \beta-H S D 2$ are mated, although this experimental model is complicated by the potential effects that life-long loss of $11 \beta$-HSD2 has on maternal care of offspring. To eliminate these effects, a heterozygous mating approach has also been taken and has been the main method for assessing the importance of $11 \beta-H S D 2$ in developmental programming.

With regard to neurodevelopment, cerebellar size is reduced in homozygously bred $11 \beta-\mathrm{HSD}^{-/-}$mice in early postnatal life due to a decrease in the molecular and internal granular layers [89]. This associates with a delay in the attainment of neurodevelopmental landmarks such as negative geotaxis and eye opening [89]. Thus, the timing of exposure of the developing brain to glucocorticoids seems to be tightly regulated by the presence of local
$11 \beta-H S D 2$ and the cell-specific patterns of its downregulation during maturation.

As adults, $11 \beta-\mathrm{HSD}^{-/-}$offspring generated from either a homozygous or heterozygous mating approach exhibit increased anxiety. Thus, exploration of the anxiogenic open arm of the elevated plus maze is reduced in $11 \beta-H S D 2^{-/-}$offspring in comparison to wild types [35]. Additionally, open field exploration is altered in the homozygously bred $11 \beta-H S D 2^{-/-}$offspring, with them being more reluctant to explore the anxiogenic central field [35]. Interestingly, open field exploration is unaltered in heterozygously bred $11 \beta-H S D 2^{-/-}$offspring, which implies that aspects of adult behaviour are influenced by maternal factors in this model [35]. The behavioural phenotype of heterozygously bred $11 \beta-\mathrm{HSD}^{-/-}$offspring has been subsequently extended with the observation that $11 \beta-H S D 2^{-/-}$offspring exhibit depressive-like behaviour. Indeed, $11 \beta-H S D 2^{-/-}$offspring spent a greater percentage of total time immobile during the tail suspension test $\left(11 \beta-\mathrm{HSD}^{+/+}: 52.73 \pm 3.5 \%\right.$ vs. $11 \beta-\mathrm{HSD}^{-/-}: 70.92 \pm$ $3.7 \%$; $<<0.05$, unpaired t test; unpubl. data) and the forced swim test $\left(11 \beta-H S D 2^{+/+}: 54.98 \pm 2.4 \%\right.$ vs. $11 \beta$ $\mathrm{HSD}^{-/-}: 68.88 \pm 4.8 \%$; $<<0.05$, unpaired t test; unpubl. data), both indicating increased depressive-like behaviour. However, it is unknown if similar behaviour is exhibited by homozygously bred $11 \beta-\mathrm{HSD}^{-/-}$offspring. Support of the notion that altered $11 \beta-H S D 2$ activity contributes to affective behaviour has also been found clinically. Thus, measurements of urinary glucocorticoids and their metabolites in depressed patients reveal changes in the intracellular regulation of glucocorticoid activity, in particular $11 \beta-\mathrm{HSD} 2$, in comparison to healthy controls [90, 91]. It is unclear, however, if this alteration in steroid metabolism is a consequence or cause of depression.

Interestingly, despite increased anxiety, the HPA axis activity of $11 \beta-\mathrm{HSD} 2^{-/-}$offspring appears unaffected, perhaps a reflection of the additional effects of attenuated HPA axis reactivity due to the reduced glucocorticoid clearance in the absence of renal 11 $\beta-H S D 2$ [35]. However, as predicted, adrenal size is reduced and hence resetting of the HPA axis may have occurred during development. This, together with a decreased degradation of corticosterone, means that less corticosterone needs to be produced. Consistent with this, $11 \beta-\mathrm{HSD} 2^{-/-}$mice exhibit no differences in the limbic expression of GR, MR or $\mathrm{CRH}$ during adulthood, but there are some transient changes within the postnatal period. In homozygous matings of $11 \beta-H S D 2^{-1-}$ mice, transient elevations in the GR transcript were observed in situ in all hippocampal 
subfields of $11 \beta-\mathrm{HSD} 2^{-/-}$offspring at postnatal day 14 [92]. Similar transient changes were observed with MR, Sgk1, Fkbp5 and BDNF [92]. It should be noted though that while no overt changes in adult HPA axis function are apparent, as $11 \beta-\mathrm{HSD} 2$ is widely expressed in the CNS during development, it still remains to be determined if the observed behavioural effects are mediated by local fine-tuning of glucocorticoids.

\section{Placental 11ß-HSD2 Is More than Just a Glucocorticoid Barrier}

As described above, placental 11ß-HSD2 may underpin aspects of developmental programming by allowing excess glucocorticoid passage from the 'high' glucocorticoid maternal circulation to the 'low' glucocorticoid fetal environment [93] and, thus, impair fetal growth by direct effects of glucocorticoids on the fetus. Fetal growth is, however, dependent on an array of maternal, placental and fetal endocrine signals, and glucocorticoid-mediated fetal growth retardation must also be related, at least in part, to disturbances in placental growth and function. Indeed, maternal treatment with dexamethasone impairs normal vascular growth in the rat placenta and has marked effects on the amino acid and glucose transport [94]. Furthermore, an elegant recent study has revealed that the placenta is a source of serotonin for the fetal forebrain [95], which, while yet to be investigated in the $11 \beta$ $\mathrm{HSD}^{-/-}$model, could also potentially impact on the development of adult affective behaviours. Nonetheless, the current data provide a convincing argument that while maternal glucocorticoids could play a direct role in programming the fetus, notably its brain, placental development and function additionally play a key role. It must be noted, however, that until tissue-specific knockouts of $11 \beta$-HSD2 in placenta and fetal tissues are developed, the differential significance of feto-placental $11 \beta-H S D 2$ for development cannot be elucidated.

\section{A Role for Altered Neuronal Serotonergic and Catecholamine Pathways?}

In addition to altered HPA axis function, early-life glucocorticoid exposure can also affect serotonergic and catecholamine pathways. Indeed, in a mouse model of prenatal stress, a depression-like phenotype was accompanied by increased serotonin (5-HT) output and decreased reuptake, as indicated by reduced 5-HT transporter levels in the hippocampus and a trend for decreased tryptophan hydroxylase-2 expression in the dorsal raphe [96]. In contrast, another model of strong prenatal restraint stress increased both serotonin and tryptophan hydroxylase expression within the dorsal raphe nuclei [97], whilst others have shown prenatal stress to decrease hippocampal $5-\mathrm{HT}_{1 \mathrm{~A}}$ receptor binding in young male offspring [98]. Neonatal handling, a model of early-life stress, increases hippocampal 5-HT levels and turnover [99, 100]. Maternal separation also has dramatic effects on the adult offspring, with an increase in the inhibitory effect of the 5-HT reuptake inhibitor citalopram on serotonergic neuron firing frequency in the dorsal raphe [101], a reduced sensitivity of $5-\mathrm{HT}_{1 \mathrm{~A}}$ receptors in the dorsal raphe [102] and layer II/III cortical pyramidal neurons [103]. Furthermore, perinatal glucocorticoid exposure increases the size and alters the distribution of adult dopaminergic populations within the substantia nigra pars compacta and the ventral tegmental area [104], while maternal dexamethasone treatment reduces serotonin turnover in the offspring [72]. Maternal protein restriction also alters serotonergic and dopaminergic systems, with the normal rise in dopamine following restraint stress of adult offspring being dampened and serotonin release enhanced [105]. Interestingly, there is evidence for serotonergic involvement in programming of the HPA axis. Thus, serotonin, via $5-\mathrm{HT}_{7}$ receptors, is involved in mediating the permanent upregulation of GR following neonatal handling $[106,107]$. Furthermore, in the rat, allelic variations in the serotonin transporter alter the changes in hippocampal GR mRNA and corticosteroid stress response that occur during postnatal stress [108].

Preliminary data suggest that altered 5-HT and catecholamine pathways in $11 \beta-H S D 2^{-/-}$adult brains may be responsible, at least in part, for anxiety-related behaviour [C.S.W., M.C.H., unpubl. obs.]. Thus, levels of 5-HT and its metabolite 5-hydroxyindole acetic acid were measured using high-performance liquid chromatography, as was dopamine and its metabolites dihydroxyphenylacetic acid, homovanillic acid and noradrenaline in homogenates of the cortex, hippocampus, hindbrain and diencephalon of 8-month-old male mice from 11 $\beta$-HSD2 heterozygous matings. Significant changes were found within the diencephalon region only, with levels of 5-HT increased by 1.6 -fold in $11 \beta$-HSD2 $2^{-/}$offspring in comparison to $11 \beta-H S D 2^{+/+}$littermates $(\mathrm{p}<0.05)$, with no change in metabolites, suggesting increased 5-HT synthesis and/or impairment of 5-HT breakdown (fig. 1). Furthermore, in the same region increases in the dopamine metabolites dihydroxyphenylacetic acid ( 1.5 fold; $\mathrm{p}<$ 
Fig. 1. Levels of serotonin (5-HT; a), dihydroxyphenylacetic acid (DOPAC; b), homovanillic acid (HVA; c) and noradrenaline $(\mathrm{NA} ; \mathbf{d})$ in the diencephalon of $11 \beta$ $\mathrm{HSD}^{+/+},{ }^{+/}$, and ${ }^{-/-}$adult male mice. Data are expressed as means \pm SEM and analysed by one-way ANOVA followed by post hoc Tukey's test; $n=7-10$ per group; * $\mathrm{p}<$ 0.05 .
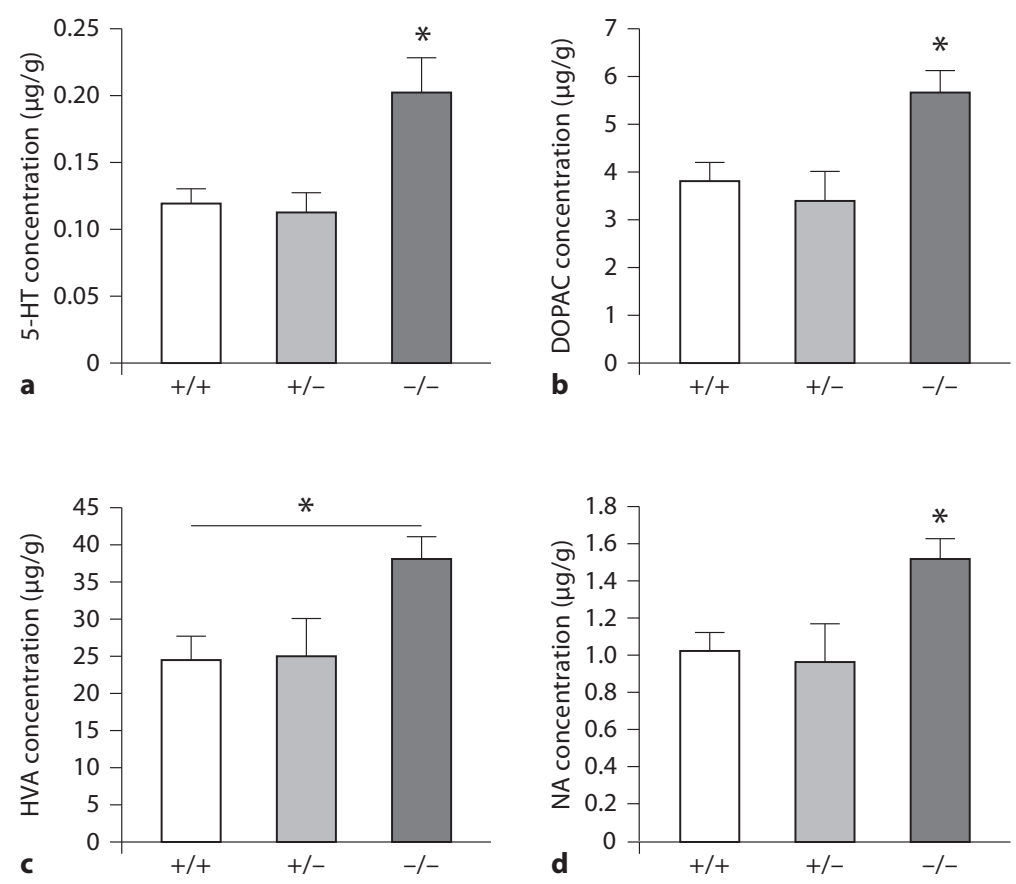

$0.05)$, homovanillic acid (1.6 fold; $\mathrm{p}<0.05)$ and noradrenaline (1.4 fold; $\mathrm{p}<0.05$ ), yet no alteration in dopamine, were found in $11 \beta-\mathrm{HSD}_{2}{ }^{-/}$offspring, indicative of increased dopamine release and/or breakdown (fig. 1). The significance of these results, particularly given that the changes were observed in the diencephalon, is currently uncertain but is suggestive of increased 5-HT synthesis and/or impaired 5-HT breakdown in addition to increased dopamine release and/or dopamine breakdown. However, these results need to be followed up with further studies to place these current findings in context, in particular, characterising dopamine and serotonin transporters, receptors and enzymes. Furthermore, while the observed monoaminergic changes in $11 \beta-H S D 2^{-/-}$offspring are unaccompanied by alteration in the HPA axis function, this does not discount a direct role for glucocorticoids in altering monoamines, as local, intracellular glucocorticoid regulation has yet to be investigated in this model.

\section{Conclusions}

In summary, prenatal exposure to glucocorticoids exerts long-term effects on the offspring, altering affective behaviours. While changes in the HPA axis are often at- tributed to underlying these altered behaviours, changes also occur within the serotonergic and catecholamine pathways. Furthermore, the development of mice in the absence of $11 \beta$-HSD2 has proven instrumental in ascertaining the significance of $11 \beta$-HSD2 for the development of affective disorders. It is interesting that a common pathway altered in the developmental programming of affective disorders, the HPA axis, is in fact marginally affected in the $11 \beta-H S D 2^{-/-}$mouse. However, preliminary data suggest that changes in serotonergic and catecholamine pathways may, at least in part, underlie the altered behaviour of $11 \beta-\mathrm{HSD}^{-/-}$mice. It should be noted though that these findings are potentially not just a consequence of feto-placental 11 $\beta$-HSD2 loss but also of life-long renal 11 $\beta$-HSD2 loss. Therefore, the development of tissue-specific knockouts of $11 \beta$-HSD2 will aid in eliminating this confounder.

\section{Acknowledgements}

This work was supported by a Wellcome Trust project grant (WT079009; M.C.H., J.L.P., J.J.M., J.R.S.). We acknowledge the support of the BHF Centre of Research Excellence. 


\section{References}

$\checkmark 1$ Cottrell EC, Seckl JR: Prenatal stress, glucocorticoids and the programming of adult disease. Front Behav Neurosci 2009;3:19.

-2 Langley-Evans SC, Phillips GJ, Benediktsson R, Gardner DS, Edwards CR, Jackson AA, Seckl JR: Protein intake in pregnancy, placental glucocorticoid metabolism and the programming of hypertension in the rat. Placenta 1996;17:169-172.

3 Gardner DS, Bell RC, Symonds ME: Fetal mechanisms that lead to later hypertension. Curr Drug Targets 2007;8:894-905.

$\checkmark 4$ Harris A, Seckl J: Glucocorticoids, prenatal stress and the programming of disease. Horm Behav 2011;59:279-289.

5 Roberts D, Dalziel S: Antenatal corticosteroids for accelerating fetal lung maturation for women at risk of preterm birth. Cochrane Database Syst Rev 2006;3:CD004454.

6 Dodic M, Hantzis V, Duncan J, Rees S, Koukoulas I, Johnson K, Wintour EM, Moritz K: Programming effects of short prenatal exposure to cortisol. FASEB J 2002;16:1017-1026.

-7 Benediktsson R, Lindsay RS, Noble J, Seckl JR, Edwards CR: Glucocorticoid exposure in utero: new model for adult hypertension. Lancet 1993;341:339-341.

-8 Dodic M, Moritz K, Koukoulas I, Wintour EM: Programmed hypertension: kidney, brain or both? Trends Endocrinol Metab 2002;13:403-408.

$\checkmark 9$ Dodic M, Peers A, Coghlan J, May C, Lumbers E, Yu Z, Wintour E: Altered cardiovascular haemodynamics and baroreceptorheart rate reflex in adult sheep after prenatal exposure to dexamethasone. Clin Sci 1999; 97:103-109.

-10 Dodic M, May CN, Wintour EM, Coghlan JP: An early prenatal exposure to excess glucocorticoid leads to hypertensive offspring in sheep. Clin Sci 1998;94:149-155.

-11 Jensen EC, Gallaher BW, Breier BH, Harding JE: The effect of a chronic maternal cortisol infusion on the late-gestation fetal sheep. J Endocrinol 2002;174:27-36

-12 Langdown ML, Sugden MC: Enhanced placental GLUT1 and GLUT3 expression in dexamethasone-induced fetal growth retardation. Mol Cell Endocrinol 2001;185:109117.

13 Levitt NS, Lindsay RS, Holmes MC, Seckl JR: Dexamethasone in the last week of pregnancy attenuates hippocampal glucocorticoid receptor gene expression and elevates blood pressure in the adult offspring in the rat. Neuroendocrinology 1996;64: $412-418$.

- 14 Gatford KL, Wintour EM, de Blasio MJ, Owens JA, Dodic M: Differential timing for programming of glucose homoeostasis, sensitivity to insulin and blood pressure by in utero exposure to dexamethasone in sheep. Clin Sci 2000;98:553-560.

Prenatal Excess Glucocorticoid Exposure and Adult Affective Disorders
15 Lindsay RS, Lindsay RM, Edwards CR, Seckl JR: Inhibition of 11-beta-hydroxysteroid dehydrogenase in pregnant rats and the programming of blood pressure in the offspring. Hypertension 1996;27:1200-1204.

16 Brown RW, Chapman KE, Kotolevtsev Y, Yau JL, Lindsay RS, Brett L, Leckie C, Murad P, Lyons V, Mullins JJ, Edwards CR, Seckl JR: Cloning and production of antisera to human placental 11 beta-hydroxysteroid dehydrogenase type 2. Biochem J 1996;313:10071017.

17 Roland BL, Krozowski ZS, Funder JW: Glucocorticoid receptor, mineralocorticoid receptors, 11 beta-hydroxysteroid dehydrogenase- 1 and -2 expression in rat brain and kidney: in situ studies. Mol Cell Endocrinol 1995;111:R1-R7.

18 Whorwood CB, Ricketts ML, Stewart PM: Epithelial cell localization of type 211 betahydroxysteroid dehydrogenase in rat and human colon. Endocrinology 1994;135. 2533-2541.

19 Roland BL, Funder JW: Localization of 11beta-hydroxysteroid dehydrogenase type 2 in rat tissues: in situ studies. Endocrinology 1996;137:1123-1128.

20 Kenouch S, Lombes M, Delahaye F, Eugene E, Bonvalet JP, Farman N: Human skin as target for aldosterone: coexpression of mineralocorticoid receptors and 11 beta-hydroxysteroid dehydrogenase. J Clin Endocrinol Metab 1994;79:1334-1341.

-21 Waddell BJ, Benediktsson R, Brown RW, Seckl JR: Tissue-specific messenger ribonucleic acid expression of 11beta-hydroxysteroid dehydrogenase types 1 and 2 and the glucocorticoid receptor within rat placenta suggests exquisite local control of glucocorticoid action. Endocrinology 1998;139:15171523

22 Burton PJ, Smith RE, Krozowski ZS, Waddell BJ: Zonal distribution of 11 beta-hydroxysteroid dehydrogenase types 1 and 2 messenger ribonucleic acid expression in the rat placenta and decidua during late pregnancy. Biol Reprod 1996;55:1023-1028.

23 Brown RW, Diaz R, Robson AC, Kotelevtsev YV, Mullins JJ, Kaufman MH, Seckl JR: The ontogeny of 11 beta-hydroxysteroid dehydrogenase type 2 and mineralocorticoid receptor gene expression reveal intricate control of glucocorticoid action in development. Endocrinology 1996;137:794-797.

24 Diaz R, Brown RW, Seckl JR: Distinct ontogeny of glucocorticoid and mineralocorticoid receptor and 11beta-hydroxysteroid dehydrogenase types I and II mRNAs in the fetal rat brain suggest a complex control of glucocorticoid actions. J Neurosci 1998;18:25702580

25 Stewart PM, Murry BA, Mason JI: Type 211 beta-hydroxysteroid dehydrogenase in human fetal tissues. J Clin Endocrinol Metab 1994;78:1529-1532.
26 Robson AC, Leckie CM, Seckl JR, Holmes MC: 11 Beta-hydroxysteroid dehydrogenase type 2 in the postnatal and adult rat brain. Brain Res Mol Brain Res 1998;61:1-10.

$>27$ Roland BL, Li KX, Funder JW: Hybridization histochemical localization of 11 beta-hydroxysteroid dehydrogenase type 2 in rat brain. Endocrinology 1995;136:4697-4700.

28 Llorente R, Gallardo ML, Berzal AL, Prada C, Garcia-Segura LM, Viveros MP: Early maternal deprivation in rats induces genderdependent effects on developing hippocampal and cerebellar cells. Int J Dev Neurosci 2009;27:233-241.

29 Mirescu C, Peters JD, Gould E: Early life experience alters response of adult neurogenesis to stress. Nat Neurosci 2004;7:841-846.

30 Wilber AA, Wellman CL: Neonatal maternal separation alters the development of glucocorticoid receptor expression in the interpositus nucleus of the cerebellum. Int J Dev Neurosci 2009;27:649-654.

-31 Meyer JS: Early adrenalectomy stimulates subsequent growth and development of the rat brain. Exp Neurol 1983;82:432-446.

>32 Murphy VE, Zakar T, Smith R, Giles WB, Gibson PG, Clifton VL: Reduced 11beta-hydroxysteroid dehydrogenase type 2 activity is associated with decreased birth weight centile in pregnancies complicated by asthma. J Clin Endocrinol Metab 2002;87:16601668

33 Stewart PM, Rogerson FM, Mason JI: Type 2 11 beta-hydroxysteroid dehydrogenase messenger ribonucleic acid and activity in human placenta and fetal membranes: its relationship to birth weight and putative role in fetal adrenal steroidogenesis. J Clin Endocrinol Metab 1995;80:885-890.

-34 Dave-Sharma S, Wilson RC, Harbison MD, Newfield R, Azar MR, Krozowski ZS, Funder JW, Shackleton CH, Bradlow HL, Wei JQ, Hertecant J, Moran A, Neiberger RE, Balfe JW, Fattah A, Daneman D, Akkurt HI, De Santis C, New MI: Examination of genotype and phenotype relationships in 14 patients with apparent mineralocorticoid excess. J Clin Endocrinol Metab 1998;83:2244-2254.

35 Holmes MC, Abrahamsen CT, French KL, Paterson JM, Mullins JJ, Seckl JR: The mother or the fetus? 11beta-hydroxysteroid dehydrogenase type 2 null mice provide evidence for direct fetal programming of behavior by endogenous glucocorticoids. J Neurosci 2006;26:3840-3844.

>36 Mune T, Rogerson FM, Nikkila H, Agarwal AK, White PC: Human hypertension caused by mutations in the kidney isozyme of 11 beta-hydroxysteroid dehydrogenase. Nat Genet 1995;10:394-399.

37 Newnham JP, Jobe AH: Should we be prescribing repeated courses of antenatal corticosteroids? Semin Fetal Neonatal Med 2009; 14:157-163. 
-38 Nyirenda MJ, Lindsay RS, Kenyon CJ, Burchell A, Seckl JR: Glucocorticoid exposure in late gestation permanently programs rat hepatic phosphoenolpyruvate carboxykinase and glucocorticoid receptor expression and causes glucose intolerance in adult offspring. J Clin Invest 1998;101:2174-2181.

-39 O’Regan D, Kenyon CJ, Seckl JR, Holmes MC: Glucocorticoid exposure in late gestation in the rat permanently programs gender-specific differences in adult cardiovascular and metabolic physiology. Am J Physiol Endocrinol Metab 2004;287:E863-E870.

40 Smith JT, Waddell BJ: Increased fetal glucocorticoid exposure delays puberty onset in postnatal life. Endocrinology 2000;141: 2422-2428.

41 Welberg LA, Seckl JR, Holmes MC: Inhibition of 11beta-hydroxysteroid dehydrogenase, the foeto-placental barrier to maternal glucocorticoids, permanently programs amygdala GR mRNA expression and anxiety-like behaviour in the offspring. Eur J Neurosci 2000;12:1047-1054.

42 Welberg LA, Seckl JR, Holmes MC: Prenatal glucocorticoid programming of brain corticosteroid receptors and corticotrophin-releasing hormone: possible implications for behaviour. Neuroscience 2001;104:71-79.

43 Wyrwoll CS, Mark PJ, Mori TA, Puddey IB, Waddell BJ: Prevention of programmed hyperleptinemia and hypertension by postnatal dietary omega-3 fatty acids. Endocrinology 2006;147:599-606.

44 Wyrwoll CS, Mark PJ, Waddell BJ: Developmental programming of renal glucocorticoid sensitivity and the renin-angiotensin system. Hypertension 2007;50:579-584.

45 Burton PJ, Waddell BJ: $11 \beta$-hydroxysteroid dehydrogenase in the rat placenta: developmental changes and the effects of altered glucocorticoid exposure. JEndocrinol 1994;143: 505-513.

46 Lucassen PJ, Bosch OJ, Jousma E, Kromer SA, Andrew R, Seckl JR, Neumann ID: Prenatal stress reduces postnatal neurogenesis in rats selectively bred for high, but not low, anxiety: possible key role of placental 11betahydroxysteroid dehydrogenase type 2 . Eur J Neurosci 2009;29:97-103.

47 Mairesse J, Lesage J, Breton C, Breant B, Hahn T, Darnaudery M, Dickson SL, Seckl J, Blondeau B, Vieau D, Maccari S, Viltart O: Maternal stress alters endocrine function of the feto-placental unit in rats. Am J Physiol Endocrinol Metab 2007;292:E1526-E1533.

-48 Pankevich DE, Mueller BR, Brockel B, Bale TL: Prenatal stress programming of offspring feeding behavior and energy balance begins early in pregnancy. Physiol Behav 2009;98:94-102.

-49 Guzman C, Cabrera R, Cardenas M, Larrea F, Nathanielsz PW, Zambrano E: Protein restriction during fetal and neonatal development in the rat alters reproductive function and accelerates reproductive ageing in female progeny. J Physiol 2006;572:97-108.
50 Lesage J, Blondeau B, Grino M, Breant B, Dupouy JP: Maternal undernutrition during late gestation induces fetal overexposure to glucocorticoids and intrauterine growth retardation, and disturbs the hypothalamo-pituitary adrenal axis in the newborn rat. Endocrinology 2001;142:1692-1702.

51 Stocker C, O’Dowd J, Morton NM, Wargent E, Sennitt MV, Hislop D, Glund S, Seckl JR, Arch JR, Cawthorne MA: Modulation of susceptibility to weight gain and insulin resistance in low birthweight rats by treatment of their mothers with leptin during pregnancy and lactation. Int J Obes Relat Metab Disord 2004;28:129-136.

52 Langley-Evans SC, Philips G, Benediktsson R, Gardner D, Edwards CR, Jackson AA Seckl JR: Maternal dietary protein restriction, placental glucocorticoid metabolism and the programming of hypertension. Placenta 1996;17:169-172.

53 Woods LL, Weeks DA: Prenatal programming of adult blood pressure: role of maternal corticosteroids. Am J Physiol Regul Integr Comp Physiol 2005;289:R955-R962.

54 Korte SM: Corticosteroids in relation to fear, anxiety and psychopathology. Neurosci Biobehav Rev 2001;25:117-142.

55 Meaney MJ, Diorio J, Francis D, Widdowson J, LaPlante P, Caldji C, Sharma S, Seckl JR, Plotsky PM: Early environmental regulation of forebrain glucocorticoid receptor gene expression: implications for adrenocortical responses to stress. Dev Neurosci 1996;18:4972 .

56 Huang WL, Beazley LD, Quinlivan JA, Evans SF, Newnham JP, Dunlop SA: Effect of corticosteroids on brain growth in fetal sheep. Obstet Gynecol 1999;94:213-218.

57 Huang WL, Harper CG, Evans SF, Newnham JP, Dunlop SA: Repeated prenatal corticosteroid administration delays astrocyte and capillary tight junction maturation in fetal sheep. Int J Dev Neurosci 2001;19:487493.

58 Sheline YI, Wang PW, Gado MH, Csernansky JG, Vannier MW: Hippocampal atrophy in recurrent major depression. Proc Natl Acad Sci USA 1996;93:3908-3913.

59 Stein MB, Koverola C, Hanna C, Torchia MG, McClarty B: Hippocampal volume in women victimized by childhood sexual abuse. Psychol Med 1997;27:951-959.

60 Bremner JD, Randall P, Scott TM, Bronen RA, Seibyl JP, Southwick SM, Delaney RC, McCarthy G, Charney DS, Innis RB: MRIbased measurement of hippocampal volume in patients with combat-related posttraumatic stress disorder. Am J Psychiatry 1995; 152:973-981.

-61 Uno H, Lohmiller L, Thieme C, Kemnitz JW, Engle MJ, Roecker EB, Farrell PM: Brain damage induced by prenatal exposure to dexamethasone in fetal rhesus macaques. I Hippocampus. Brain Res Dev Brain Res 1990;53:157-167.
62 Mandyam CD, Crawford EF, Eisch AJ, Rivier CL, Richardson HN: Stress experienced in utero reduces sexual dichotomies in neurogenesis, microenvironment, and cell death in the adult rat hippocampus. Dev Neurobiol 2008;68:575-589.

63 Nagano M, Ozawa H, Suzuki H: Prenatal dexamethasone exposure affects anxietylike behaviour and neuroendocrine systems in an age-dependent manner. Neurosci Res 2008;60:364-371.

64 Alonso SJ, Damas C, Navarro E: Behavioral despair in mice after prenatal stress. J Physiol Biochem 2000;56:77-82.

65 Hauser J, Feldon J, Pryce CR: Direct and dam-mediated effects of prenatal dexamethasone on emotionality, cognition and HPA axis in adult Wistar rats. Horm Behav 2009; 56:364-375.

66 Estanislau C, Morato S: Prenatal stress produces more behavioral alterations than maternal separation in the elevated plus-maze and in the elevated T-maze. Behav Brain Res 2005; 163:70-77.

67 Murmu MS, Salomon S, Biala Y, Weinstock M, Braun K, Bock J: Changes of spine density and dendritic complexity in the prefrontal cortex in offspring of mothers exposed to stress during pregnancy. Eur J Neurosci 2006;24:1477-1487.

68 Vallee M, Mayo W, Dellu F, Le Moal M, Simon $\mathrm{H}$, Maccari S: Prenatal stress induces high anxiety and postnatal handling induces low anxiety in adult offspring: correlation with stress-induced corticosterone secretion. J Neurosci 1997;17:2626-2636.

69 Dickerson PA, Lally BE, Gunnel E, Birkle DL, Salm AK: Early emergence of increased fearful behavior in prenatally stressed rats. Physiol Behav 2005;86:586-593.

70 Takahashi LK, Turner JG, Kalin NH: Prenatal stress alters brain catecholaminergic activity and potentiates stress-induced behavior in adult rats. Brain Res 1992;574:131-137.

71 Ward HE, Johnson EA, Salm AK, Birkle DL: Effects of prenatal stress on defensive withdrawal behavior and corticotropin releasing factor systems in rat brain. Physiol Behav 2000;70:359-366.

72 Muneoka K, Mikuni M, Ogawa T, Kitera K, Kamei K, Takigawa M, Takahashi K: Prenatal dexamethasone exposure alters brain monoamine metabolism and adrenocortical response in rat offspring. Am J Physiol 1997; 273:R1669-R1675.

73 Cratty MS, Ward HE, Johnson EA, Azzaro AJ, Birkle DL: Prenatal stress increases corticotropin-releasing factor (CRF) content and release in rat amygdala minces. Brain Res 1995;675:297-302.

74 Maccari S, Morley-Fletcher S: Effects of prenatal restraint stress on the hypothalamus-pituitary-adrenal axis and related behavioural and neurobiological alterations. Psychoneuroendocrinology 2007;32(suppl 1):S10-S15. 
75 Pardon MC, Rattray I: What do we know about the long-term consequences of stress on ageing and the progression of age-related neurodegenerative disorders? Neurosci Biobehav Rev 2008;32:1103-1120.

76 Sloboda DM, Moss TJ, Gurrin LC, Newnham JP, Challis JR: The effect of prenatal betamethasone administration on postnatal ovine hypothalamic-pituitary-adrenal func tion. J Endocrinol 2002;172:71-81.

77 Moss TJ, Doherty DA, Nitsos I, Sloboda DM, Harding R, Newnham JP: Effects into adulthood of single or repeated antenatal corticosteroids in sheep. Am J Obstet Gynecol 2005; 192:146-152.

78 de Vries A, Holmes M, Heijnis A, Seier J, van Heerden J, Louw J, Wolfe-Coote S, Meaney M, Levitt N, Seckl J: Prenatal dexamethasone exposure induces changes in nonhuman primate offspring cardiometabolic and hypothalamic-pituitary-adrenal axis function. J Clin Invest 2007;117:1058-1067.

79 Uno H, Eisele S, Sakai A, Shelton S, Baker E, DeJesus O, Holden J: Neurotoxicity of glucocorticoids in the primate brain. Horm Behav 1994;28:336-348.

-80 Yehuda R, Engel SM, Brand SR, Seckl J, Marcus SM, Berkowitz GS: Transgenerational effects of posttraumatic stress disorder in babies of mothers exposed to the world trade center attacks during pregnancy. J Clin Endocrinol Metab 2005;90:4115-4118.

-81 Yehuda R, Teicher MH, Seckl JR, Grossman RA, Morris A, Bierer LM: Parental posttraumatic stress disorder as a vulnerability factor for low cortisol trait in offspring of holocaust survivors. Arch Gen Psychiatry 2007;64: 1040-1048.

$>82$ O'Connor TG, Ben-Shlomo Y, Heron J, Golding J, Adams D, Glover V: Prenatal anxiety predicts individual differences in cortisol in pre-adolescent children. Biol Psychiatry 2005;58:211-217.

-83 Van den Bergh BR, Van Calster B, Smits T, Van Huffel S, Lagae L: Antenatal maternal anxiety is related to HPA-axis dysregulation and self-reported depressive symptoms in adolescence: a prospective study on the fetal origins of depressed mood. Neuropsychopharmacology 2008;33:536-545

84 Benediktsson R, Calder AA, Edwards CR, Seckl JR: Placental 11 beta-hydroxysteroid dehydrogenase: a key regulator of fetal glucocorticoid exposure. Clin Endocrinol 1997; 46:161-166.

-85 Raikkonen K, Pesonen AK, Heinonen K, Lahti J, Komsi N, Eriksson JG, Seckl JR, Jarvenpaa AL, Strandberg TE: Maternal licorice consumption and detrimental cognitive and psychiatric outcomes in children. Am J Epidemiol 2009;170:1137-1146.
86 Raikkonen K, Seckl JR, Heinonen K, Pyhala R, Feldt K, Jones A, Pesonen AK, Phillips DI, Lahti J, Jarvenpaa AL, Eriksson JG, Matthews KA, Strandberg TE, Kajantie E: Maternal prenatal licorice consumption alters hypothalamic-pituitary-adrenocortical axis function in children. Psychoneuroendocrinology 2010;35:1587-1593.

87 Fride E, Weinstock M: Prenatal stress increases anxiety related behavior and alters cerebral lateralization of dopamine activity. Life Sci 1988;42:1059-1065.

88 Kotelevtsev Y, Brown RW, Fleming S, Kenyon C, Edwards CR, Seckl JR, Mullins JJ: Hypertension in mice lacking 11beta-hydroxysteroid dehydrogenase type 2. J Clin Invest 1999; 103:683-689.

89 Holmes MC, Sangra M, French KL, Whittle IR, Paterson J, Mullins JJ, Seckl JR: 11betahydroxysteroid dehydrogenase type 2 protects the neonatal cerebellum from deleterious effects of glucocorticoids. Neuroscience 2006;137:865-873.

90 Römer B, Lewicka S, Kopf D, Lederbogen F, Hamann B, Gilles M, Schilling C, Onken V, Frankhauser P, Deuschle M: Cortisol metabolism in depressed patients and healthy controls. Neuroendocrinology 2009;90:301306.

-91 Poor V, Juricskay S, Gati A, Osvath P, Tenyi T: Urinary steroid metabolites and 11betahydroxysteroid dehydrogenase activity in patients with unipolar recurrent major depression. J Affect Disord 2004;81:55-59.

92 Wyrwoll CS, Holmes MC, Seckl JR: 11betahydroxysteroid dehydrogenases and the brain: from zero to hero, a decade of progress. Front Neuroendocrinol 2011;32:265286.

93 Edwards CR, Benediktsson R, Lindsay RS, Seckl JR: Dysfunction of placental glucocorticoid barrier: link between fetal environment and adult hypertension? Lancet 1993; 341:355-357

94 Hewitt DP, Mark PJ, Waddell BJ: Glucocorticoids prevent the normal increase in placental vascular endothelial growth factor expression and placental vascularity during late pregnancy in the rat. Endocrinology 2006;147:5568-5574.

95 Bonnin A, Goeden N, Chen K, Wilson ML, King J, Shih JC, Blakely RD, Deneris ES, Levitt P: A transient placental source of serotonin for the fetal forebrain. Nature 2011; 472:347-350.

96 Mueller BR, Bale TL: Sex-specific programming of offspring emotionality after stress early in pregnancy. J Neurosci 2008;28: 9055-9065.

$\checkmark 97$ Miyagawa K, Tsuji M, Fujimori K, Saito Y, Takeda H: Prenatal stress induces anxietylike behavior together with the disruption of central serotonin neurons in mice. Neurosci Res 2011;70:111-117.
98 Van den Hove DL, Lauder JM, Scheepens A, Prickaerts J, Blanco CE, Steinbusch HW: Prenatal stress in the rat alters 5-HT1A receptor binding in the ventral hippocampus. Brain Res 2006;1090:29-34.

$\checkmark 99$ Mitchell JB, Iny LJ, Meaney MJ: The role of serotonin in the development and environmental regulation of type II corticosteroid receptor binding in rat hippocampus. Brain Res Dev Brain Res 1990;55:231-235.

100 Smythe JW, Rowe WB, Meaney MJ: Neonatal handling alters serotonin (5-HT) turnover and 5-HT2 receptor binding in selected brain regions: relationship to the handling effect on glucocorticoid receptor expression. Brain Res Dev Brain Res 1994; 80:183-189.

101 Arborelius L, Hawks BW, Owens MJ, Plotsky PM, Nemeroff CB: Increased responsiveness of presumed 5-HT cells to citalopram in adult rats subjected to prolonged maternal separation relative to brief separation. Psychopharmacology 2004; 176:248-255.

102 Gartside SE, Johnson DA, Leitch MM, Troakes C, Ingram CD: Early life adversity programs changes in central 5-HT neuronal function in adulthood. Eur J Neurosci 2003; 17:2401-2408.

103 Goodfellow NM, Benekareddy M, Vaidya VA, Lambe EK: Layer II/III of the prefrontal cortex: inhibition by the serotonin 5-HT1A receptor in development and stress. J Neurosci 2009;29:10094-10103.

104 McArthur S, McHale E, Gillies GE: The size and distribution of midbrain dopaminergic populations are permanently altered by perinatal glucocorticoid exposure in a sex-, region- and time-specific manner. Neuropsychopharmacology 2007;32:1462-1476.

105 Mokler DJ, Torres OI, Galler JR, Morgane PJ: Stress-induced changes in extracellular dopamine and serotonin in the medial prefrontal cortex and dorsal hippocampus of prenatally malnourished rats. Brain Res 2007; 1148:226-233.

106 Mitchell JB, Rowe W, Boksa P, Meaney MJ: Serotonin regulates type II corticosteroid receptor binding in hippocampal cell cultures. J Neurosci 1990;10:1745-1752.

107 Meaney MJ, Diorio J, Francis D, Weaver S, Yau J, Chapman K, Seckl JR: Postnatal handling increases the expression of cAMP-inducible transcription factors in the rat hippocampus: the effects of thyroid hormones and serotonin. J Neurosci 2000;20:39263935.

108 Belay H, Burton CL, Lovic V, Meaney MJ, Sokolowski M, Fleming AS: Early adversity and serotonin transporter genotype interact with hippocampal glucocorticoid receptor mRNA expression, corticosterone, and behavior in adult male rats. Behav Neurosci 2011;125:150-160. 